FANNY MARCON 다 https://orcid.org/0000-0001-9361-157X

GIULIO PERUZZI (1) https://orcid.org/0000-0001-8331-1864

SOFIA TALAS 두 https://orcid.org/0000-0003-1971-8680

University of Padua

\title{
The Physics Cabinet of the University of Padua. At the crossroads between Veneto and Europe
}

ABSTRACT

At the beginning of the eighteenth century, new lectures in natural philosophy based on direct and immediate demonstrations began to spread through Europe. Within this context, a chair of experimental philosophy was created at the University of Padua in 1738, and the new professor, Giovanni Poleni, established a Cabinet of Physics, which became very well known in eighteenth-century Europe. In the following two centuries, Poleni's successors continued to acquire thousands of instruments used for teaching and research, which today are held at the Museum of the History of Physics of the University of Padua. The present paper describes the main peculiarities of the collection, comprising instruments from the Renaissance to the twentieth century. We also discuss the current acquisition policy of the museum, aimed at collecting material evidence of the research and teaching activities in physics that are carried out in Padua today. We will outline both the local peculiarities of the collection and its international dimension, based on the contacts that have been established throughout the centuries between Padua and the international scientific community. Some aspects of the circulation of scientific knowledge in Europe and beyond will thus also emerge.

Keywords: scientific instruments from $16^{\text {th }}$ to $21^{\text {st }}$ century, teaching and research devices, circulation of knowledge, physics, astronomy

Słowa kluczowe: instrumenty naukowe od XVI do XXI wieku, przyrządy dydaktyczne i badawcze, obieg wiedzy, fizyka, astronomia 
The experimental physics room was established a few years ago by the Marquis Poleni; he has gathered a large collection of machines of all sorts, made in France, in England, in Holland, under the eye of the best Physicists; many of them were devised or improved by Poleni himself, and I do not know of a more beautiful Cabinet of Physics. ${ }^{1}$

With these words, the French astronomer Joseph-Jérôme de Lalande described the Cabinet of Physics he visited and admired at the University of Padua in 1765. Such a collection had been set up for the lecture courses on experimental natural philosophy that had been introduced at the University of Padua a few years before, with the creation of a chair of Experimental Philosophy in 1738. Giovanni Poleni, who was assigned the new chair, gathered a first group of machines within a couple of years and he continued to enrich the collection until his death, in 1761. Intended for teaching and research, the equipment had to be regularly updated according to the development of science and, in the following centuries, thousands of new instruments were acquired as well as some older devices of the sixteenth and seventeenth century, which were regarded as useful teaching tools. All these instruments now constitute the collection of the Museum of the History of Physics, housed at the Department of Physics and Astronomy of the University of Padua. The present paper will outline a description of the collection, its main features and a few of its highlights. We will focus on the creation of the Cabinet of Physics in the eighteenth century, outline the scientists who mainly enlarged it in the nineteenth and twentieth centuries, and discuss some of the Museum's latest acquisitions. We will see how, though deeply rooted in the history of the University of Padua and its region, the Museum of the History of Physics also shows a strong European and international dimension.

It is worth pointing out that, at the beginning of the eighteenth century, the teaching of natural philosophy at the University of Padua was based on the reading of Aristotle's works. No experiment-based course existed, which was quite current in almost all European universities. Then, at the beginning of the eighteenth century, under Newton's influence, new experimental physics lectures were introduced in Cambridge and Oxford and lecture-demonstrations were proposed in London to a wide public. ${ }^{2}$ One of the most prominent lecturers of the time was John Theophilus Desaguliers, whose book $A$ course of experimental philosophy was translated into many different languages and was very popular during the whole eighteenth century. ${ }^{3}$ Two Dutchmen, strenuous supporters of Newton's ideas, Willem Jacob's Gravesande and Pieter van Musschenbroek, introduced the new physics lectures at the universities of Leiden, Duisburg and Utrecht. ${ }^{4}$ They focused on performing demonstrations in order to disseminate Newtonian philosophy, which

1 J.-J. de Lalande, Voyage d'un François en Italie, Fait dans les années 1765 et 1766, Paris 1769 , Vol. 8, pp. 285-286 ("La salle de physique expérimentale, fut établie il y a quelques années par le Marquis Poleni; il y a rassemblé une ample collection de machines de toute espece, faites en France, en Angleterre, en Hollande, sous les yeux des meilleurs Physiciens; plusieurs ont été imaginées ou perfectionnées par M. Poleni lui-même, \& je ne connois gueres de plus beau cabinet de Physique").

2 A.Q. Morton, J.A. Wess, Public and private science - The King George III Collection, OxfordLondon 1993.

3 J.T. Desaguliers, A course of experimental philosophy, 2 Vol., London 1734-1744.

${ }^{4}$ P. de Clercq, The Leiden Cabinet of Physics, Leiden 1997; idem, At the sign of the oriental lamp: the Musschenbroek workshop in Leiden, 1660-1750, Rotterdam 1997. 
was regarded as brilliant but difficult to understand. As 's Gravesande wrote to Newton in 1718, machines were regarded as crucial means "to convey the force of propositions." Instruments were actually used to give direct and immediate demonstrations of the laws of physics. Excellent lecturers, 's Gravesande and Musschenbroek had their treatises published in several editions and translated into various languages. ${ }^{6}$ They became widely known and attracted students from all over Europe, like Jean-Antoine Nollet, who was also to become one of the main representatives of the new way of teaching. ${ }^{7}$ In a few decades, the new physics lectures thus spread all over Europe, in the universities as well as at Courts and in Salons. ${ }^{8}$ Chairs of experimental physics were created in many European universities and more and more Cabinets of Physics, homogeneous collections of scientific instruments for research and teaching purposes, were set up. The new physics treatises, the letters exchanged between scholars, the instruments that were sent around by makers and scholars, as well as the journeys made by the elite, contributed to such a wide and quick spread across Europe. ${ }^{9}$

As for Padua, a growing need for change was felt from the early eighteenth century. Experimental natural philosophy had been practised in Venice from the seventeenth century, in particular at the Sarotti Academy, founded in 1681 on the model of the Royal Society. ${ }^{10}$ This is to say that the Venetian patricians, who were in charge of ruling at that time the University of Padua - Padua was under the rule of Venice from 1405, were well aware of the development of the new scientific practices. From 1715 onwards, several documents were proposed, stressing that it was urgent to achieve a general reform of the University in order to eliminate old-fashioned chairs and create new ones. ${ }^{11}$ The two most important of these proposals, written respectively by Scipione Maffei in 1715 and by Giovanni Francesco Pivati in 1738, both suggested the creation of a chair of experimental philosophy. Such a chair was finally institutionalized by the Venetian Senate

${ }^{5}$ P. de Clercq, At the sign..., note 4, p. 76.

${ }^{6}$ Among these treatises, let's mention for instance W.'s Gravesande's Physices elementa mathematica, experimentis confirmata, sive introductio ad philosophiam Newtonianam, which was published for the first time in Leiden in 1720-1721; P. van Musschenbroek's Elementa physicae, published in Leiden in 1734, and his Introductio ad philosophiam naturalem, published at first in Leiden in 1762.

7 J.L. Heilbron, Nollet, Jean Antoine [in:] Dictionary of scientific biography, 16 Vol., New York 1970-1980, v. 10; The art of teaching physics: the eighteenth-century demonstration apparatus of Jean Antoine Nollet, eds. L. Pyenson, J.F. Gauvin, Sillery 2002.

${ }^{8}$ About these lectures, see S. Talas, Physics in the eighteenth century: new lectures, entertainment and wonder [in:] Laura Bassi - Emblema e primato nella scienza del Settecento - Emblem and primacy in Settecento science, eds. L. Cifarelli, R. Simili, Bologna 2012, pp. 177-188 and idem, La fisica nel Settecento: nuove lezioni, spettacolo, meraviglia, "Il Nuovo Saggiatore" 2011, Vol. 27, No. 5-6, pp. 37-47.

${ }^{9}$ About the Cabinets of Physics in eighteenth-century Europe, see Cabinets of experimental philosophy in eighteenth-century Europe, eds. J. Bennett, S. Talas, Leiden-Boston 2013.

${ }_{10}$ The meetings of this academy were attended for two years by Denis Papin. See for instance D. Papin, Continuation du Digesteur ou manière d'amolir les os, Amsterdam 1788 (Section III, pp. 164-240, describes the "Expériences faites dans l'Académie de M. Sarotti de Venise").

${ }^{11}$ P. Del Negro, L'Università [in:] Storia della cultura veneta, eds. G. Arnaldi, M. Pastore Stocchi, Vicenza 1976-1986, 10 Vol.; Vol. 5/I: Il Settecento, pp. 47-76. 
on 27 November 1738 and a couple of months later, on 12 February 1739, it was assigned to Poleni.

The preserved documents show that the Venetian authorities were eager to make the new chair of experimental philosophy as successful as possible, and the choice of an adequate professor was thus crucial. ${ }^{12}$ Giovanni Poleni was chosen, but why? Several researches have already focused on him not only as a scientist, but as a philologist and an acknowledged expert in architecture and classical antiquity as well. ${ }^{13}$ Let us only remind that Poleni was born in Venice in 1683 and that he published on a wide variety of scientific topics ranging from calculating machines to navigation instruments, from sundials to thermometers, from astronomy to hydraulics. Member of the main academies of his time - Royal Society, Academies of Sciences of Paris, Berlin and Saint Petersburg, only to mention a few - he was in touch with many prominent figures of his time, such as Newton, Euler, Maupertuis, Nollet, Johann I, Daniel I and Nicolaus I Bernoulli, Jallabert, Boscovich, Leibniz, Celsius, Delisle, 's Gravesande and Musschenbroek. He was successively assigned several chairs at the University of Padua: the chair of Astronomia e meteore in 1709, the chair of Philosophia ordinaria in secundo loco in 1715 and, in 1719 , the prestigious chair of mathematics, that had been occupied by Galileo and other outstanding scientists, like Jacob Hermann and Nicolaus I Bernoulli.

Poleni also successfully practiced experimental natural philosophy for years, from the early eighteenth century, when he was still living in Venice. He was actually regarded at the time as an expert of scientific instruments, renowned throughout Europe. His correspondence with Giovanni Giacomo Marinoni, mathematician, topographer and astronomer at the Imperial Court in Vienna, is paradigmatic in this sense. In 1725, for instance, Marinoni asked Poleni's advices to build a double-barrelled air-pump on the model of Hauksbee's. He focused on very technical details that show the high competence Poleni was supposed to have. ${ }^{14}$ The Venetian scholar thus undoubtedly fit the peculiarities of the new chair of experimental philosophy, which needed both theoretical knowledge and experimental skills. The goal was to set up a totally new course - new content, new structure - with a totally new methodology: for the first time, the professor was not expected to simply read and comment a text, but he had to present scientific theories and carry out demonstrations at the same time.

Well aware of the challenges he had to face, Poleni felt extremely worried and complained that "Old as I am, and with these health problems (...). I did not feel strong enough

${ }^{12}$ About the beginnings of the experimental philosophy lectures in Padua and the creation of the Cabinet of Physics, see S. Talas, New Light on the Cabinet of Physics of Padua [in:] Cabinets of Experimental Philosophy in Eighteenth-Century Europe, eds. J. Bennett, S. Talas, Leiden-Boston 2013, pp. 49-67; S. Talas, Il gabinetto di filosofia sperimentale di Poleni [in:] Giovanni Poleni tra Venezia e Padova, eds. P. Del Negro, Venezia 2013, pp. 247-275.

13 AA.VV., Giovanni Poleni nel bicentenario della morte, Padua 1963; AA.VV., Giovanni Poleni, idraulico, matematico, architetto, filologo, Padua 1988; G.A. Salandin, M. Pancino, Il Teatro di Filosofia Sperimentale di Giovanni Poleni, Trieste 1987; G.A. Salandin, S. Talas, Giovanni Poleni [in:] AA. V., La curiosità e l'ingegno, Padua 2000, pp. 85-91; G.A. Salandin, S. Talas, Strumenti e macchine [in:] AA.VV., La curiosità..., pp. 223-243.

${ }_{14}$ Biblioteca civica Verona (BCVr), Carteggio Poleni, Vol. 8. 
to accept such a burden (...). I shall say as the English say, let's see."15 In the numerous letters he sent to various Venetian officials and to personal friends, Poleni explained his three major worries. First of all, he needed someone who could help him to "prepare the machines" and "carry out the experiments", ${ }^{16}$ and he asked for an adequate place where to hold the new lectures. He also needed funds, as his lectures required quite a number of instruments. ${ }^{17} \mathrm{He}$ already had some instruments of his own and, before he was assigned the chair, the Venetian magistrates had got in touch with the heirs of Cristino Martinelli, a Venetian patrician member of the Sarotti Academy, in order to buy some of his instruments. Poleni chose five of these devices, which encompassed a double-barrelled air-pump, very similar to Hauksbee's design, an artificial magnet and a camera obscura, that are still kept at the Museum (Fig. I). However, these instruments were hardly sufficient for one or two lectures. ${ }^{18}$

In a very short lapse of time, within a few months, the Venetian authorities fulfilled all Poleni's requests. The scholar was provided with assistants he personally selected. One of them, Giovanni Antonio Dalla Bella was to lecture on experimental philosophy in Lisbon from 1766, setting up a rich Cabinet of Physics that was moved to the University of Coimbra in 1772. Poleni was also assigned funds to buy instruments on a regular basis. The university Cabinet of Physics in Padua was thus one of the first in Europe to be fully financed by public funds. Of the about four hundred instruments that originally made up Poleni's Cabinet of Physics, one hundred survived and are now housed at the Museum of the History of Physics. As for the lecturing place, Poleni was charged, together with his friend Giovanni Battista Morgagni, the well-known physician, with planning and supervising renovation works in the historical building of the University, the Palazzo del Bo. Specially designed rooms were set up to store the instruments and carry out experiments, and a theatre was built for the lectures. Poleni explained that he limited the theatre to one hundred seats, because "if the place [the theatre - F.M.] was larger, part of the audience would be too far and could not learn, as the experiments are meant to be seen". ${ }^{19}$

As for Poleni's way of lecturing on experimental natural philosophy, it mainly followed the English and Dutch Newtonians. He often and enthusiastically mentions in his letters Desaguliers but, above all, 's Gravesande and Musschenbroek. Moreover, the manuscript of a textbook, never completed, where Poleni gave detailed descriptions of his weekly lectures, was titled Physices elementa mathematica, experimentis confirmata, just like's

15 Poleni to Maffei, 23 February 1739: Biblioteca Marciana Venezia (BMVe), ms. it., X, c. 94 ("Io veramente in questa età, e con questi acciacchi (...) non mi sentiva in istato di assumere questo peso (...). Dirò come dicono gli Inglesi, vedremo".

${ }^{16}$ Poleni to Gadaldini, 18 March 1739: BMVe, ms. it., IV, 592 (=5555), cc. 185-186 ("quando apparecchieremo le machine e quando dirigeremo gli esperimenti").

17 Poleni to Bianchi, 1 July 1739: Archivio di Stato Venezia (ASVe), Riformatori allo Studio di Padova, Filza 211.

18 Ibidem.

19 Morgagni and Poleni to the Riformatori, 13 September 1739: ASVe, Riformatori allo Studio di Padova, Filza 211 ("se il luogo fosse maggiore, quelli che fossero di più per necessità dovrebbero essere più lontani, né sarebbero a portata di ricavar frutto, perché gl'esperimenti sono per quelli che stanno vicini a poterli vedere"). 
Gravesande's well known treatise. ${ }^{20}$ The lectures themselves had the typical structure of the experimental philosophy lectures of those years with definitions, descriptions of instruments and experiments, explanations. His textbook gave a full bibliography of the books he based his lectures on and, here again, the names of 's Gravesande, Musschenbroek and Desaguliers recur very often, together with other scientists like Nollet, Rohault, Newton or Kepler. According to the fashion of the time, Poleni carried out various spectacular experiments to catch the attention of his public - he used for instance a Hero's fountain, pouring in water and observing how a jet of wine was spouted out thus combining utility with pleasure, as Nollet suggested (Fig. II). ${ }^{21}$

Of course, most of the instruments were intended for teaching but, as Poleni was a scientist and a researcher himself, ${ }^{22}$ he was also interested in having instruments for his own researches. He used for instance his macchina divulsoria, an apparatus very similar to Musschenbroek's original model, to study the strength of materials when he worked on the restoration of Saint Peter Cupola in Rome, in the years 1742-1748. ${ }^{23}$ Poleni had been chosen by the Pope of the time, Benedict XIV, to take care of the restoration of the Cupola, who seemed about to collapse. Luigi Vanvitelli was at the time the official "architect" of the Cupola and Poleni worked in tight collaboration with him, acting as what we would call today a kind of "scientific consultant", who actually took all the main decisions. Poleni decided to reinforce the Cupola with iron rings and, to decide the section of these rings, he carried out measurements with his macchina divulsoria, which is still kept at the Museum of the History of Physics (Fig. III and IV).

Though most of the instruments Poleni purchased were cutting-edge devices, some devices were older. He acquired for instance a compass made by "the famous Venetian Bernardo Facini," a lens of "28 palms, worked by the Illustrious Geminiano Montanari," and a telescope signed by the well-known instrument-maker Giuseppe Campani. ${ }^{24} \mathrm{He}$ also bought in 1745 a microscope signed "Eustachio Divini in Roma 1671." Particularly tall and made of five tubes inserted one into the other, this microscope is the only surviving instrument of this kind and the only existing microscope signed by Divini, one of the best optical instrument-makers of the seventeenth century (Fig. V). Most of these older instruments were thus particularly valuable due to their inventor or maker, but it is worth underlining that Poleni, quite pragmatically, acquired them all with the main intent of using them for teaching.

As for the largest part of his Cabinet, Poleni had his instruments built by local craftsmen. Several different craftsmen usually contributed to the construction of a single instrument. To make his central forces machine, for instance, Poleni had a goldsmith,

${ }^{20}$ G. Poleni, Physices elementa mathematica, experimentis confirmata: BMVe, ms. lat., cl. VIII, 144-146 (=2721-2723).

21 J.A. Nollet, Programme ou idée générale d'un cours de physique expérimentale, Paris 1738 , p. xi.

22 This was not always the case, as professors of experimental physics were usually not supposed to carry out researches at all at that time (J.L. Heilbron, op. cit., note 7, pp. 134-137).

23 G. Poleni, Memorie istoriche della gran cupola del Tempio Vaticano, Padua 1748.

${ }^{24}$ Idem, Indice delle macchine: BMVe, ms. it., III, 54-55 = 4969-4970, cl. IV, 626 = 5488, 636= 5497. 
a blacksmith, a wood turner and a joiner working for him. ${ }^{25}$ Though Poleni also designed several devices himself, ${ }^{26}$ most of his instruments were based on the main physics treatises of those years, in particular on Dutch models. His central forces machine and the apparatus to study the elasticity of materials, for instance, were built according to 's Gravesande's design.

Besides the locally made instruments - about 300 of the 386 natural philosophy instruments listed in his catalogue from 1741 to 1761 - Poleni also acquired instruments from various places. He bought for instance twenty-four instruments from the Musschenbroek workshop in Leyden and six devices from Nollet. Many of these are preserved, such as a prism, a Papin steam digester and a balance to study the action of forces, made by Jan van Muscchenbroek, as well as a device to analyse friction made in Nollet's workshop (Fig. VI). Other instruments came from various parts of Italy, from the most disparate people.

In 1742, for instance, Poleni bought from Giulio Accetta, professor of mathematics at the University of Turin, a crane and other models of machines made by Accetta himself. ${ }^{27}$ From the Duchy of Modena, Poleni received a balance made by an Artillery Colonel, Domenico Corradi d'Austria. Bartolomeo Ferracina, mechanics and clock-maker, who restored in the 1750s the tower clock of Piazza San Marco in Venice, also made for Poleni several instruments, such as the model of a pile-driver that he had designed to reconstruct the bridge designed by Palladio in Bassano. Ferracina's pile-driver was particularly effective, as it could lift a mass of $350 \mathrm{~kg}$ to a height of seven meters twice in five minutes, so that it was possible to hammer two or three posts per day. Poleni wanted to have a model of it for his Cabinet of Physics, thus shedding light on his interest for the practical and technical issues of the territory (Fig. VII). Two other models of piledrivers were sent to Poleni by Count Carlo Gazzola, a Veronese nobleman involved in the socially useful applications of experimental philosophy. ${ }^{28}$

Of course, Poleni also got in touch with the very few specialised makers active in the country as well. One of these, Domenico Selva, was an optical maker in Venice with an excellent reputation in Europe. From this workshop, Poleni bought mirrors, a magic lantern, a prismatic lens and a telescope. As for thermometers, barometers and other glass instruments, Poleni acquired many of them in Como, which was to become one of the main European centres for this kind of craftsmanship. Poleni bought some other instruments from Carlo Antonio Castelnuovo who held public demonstrations on electricity and provided Poleni with a solar microscope, a prism, an artificial magnet and some accessories for electrical experiments.

Furthermore, through Antonio Agelli, a member of the Inquisition who had moved from Venice to Florence, Poleni got in touch with a particularly skilful and talented

${ }^{25}$ Note e ricevute delle spese fatte per l'artificiosissima machina, con cui si fanno e si mostrano gli esperimenti delle forze centrali, Padua, Archivio per la Storia dell'Università di Padova (ASUP), busta 591.

${ }^{26}$ He devised for instance an apparatus to study the velocity of falling bodies, where he used a kind of mercury chronometer to measure time, and a device to draw logarithmic and tractorial curves, which was much appreciated by Euler.

27 G. Poleni, Conti di spese per macchine: ASUP, busta 591; idem, Indice..., note 23.

${ }^{28}$ Gazzola to Poleni, 18 August 1748: BCVr, busta 217. 
maker, Philippe Vayringe. ${ }^{29}$ Born in 1684 in Lorraine, in a family of peasants, Vayringe had worked as a locksmith and a clock-maker. ${ }^{30}$ Sent by Leopold, Duke of Lorraine, to England in order to learn instrument-making, he worked at Desaguliers' workshop and then made for the Duke Leopold, at the castle of Lunéville, a complete set of instruments in addition to those he brought from London, thus arousing the admiration of Voltaire, who wrote in 1735 :

I was at the court of Lorraine (...). There is an admirable place established for sciences (...) furnished with the new physics experiments, and in particular with everything that confirms the Newtonian system. There are about ten thousand crowns worth machines of all kind. (...) There is nothing similar to this establishment in France. ${ }^{31}$

Not only a skilled instrument-maker but a "philosopher" as well, Vayringe also gave lectures on natural philosophy at the Académie de Lunéville, founded by the Duke.

When the Lorraine Court moved from Lunéville to Florence in 1737, the collection of instruments was transferred to Palazzo Pitti and, though invited to stay in Lunéville by the new lord, Stanislas of Poland, Vayringe decided to move to Florence too. During the trip, he stopped in the Netherlands and met 's Gravesande in Leiden and Musschenbroek in Utrecht. Very active, he started proposing in Florence the lectures he had held in Lunéville, but he was to face a cruel disappointment: for various reasons, the young nobles of the town did not pay attention to his courses. Vayringe thus started to make and sell instruments of extraordinary quality, which Poleni eagerly bought. Let's mention, among Vayringe's instruments that are still kept in Padua, a device to study the refraction of light in liquids, which Poleni enthusiastically described to Francesco Algarotti in $1746,{ }^{32}$ a beautifully engraved device to show the tautochronism of the cycloid, and an instrument made of a pair of metal wires fixed on a paraboloid (Fig. VIII). Invented in 1699 by Jean Truchet, this instrument is extremely rare: there is only another one in Florence, at the Museo Galileo, constructed by an unknown maker.

Poleni's Cabinet of Physics of Padua is thus the result of the circulation of instruments, scientists, makers and treatises in eighteenth-century Europe. Poleni himself actively contributed to this circulation towards Portugal - through the work of Dalla Bella in Lisbon and Coimbra - and towards Greece - some of Poleni's Greek students were among the scholars who introduced experimental physics in Greece. ${ }^{33}$ Padua was thus totally involved in the spread of experimental philosophy lectures and physics collections

${ }^{29}$ Carteggio Poleni: BCVr, Vol. 3, and BMVe, ms. it., IV, 643 (= 5504).

${ }^{30}$ An autobiography of Vayringe was comunicated by his friend Duval to Augustin Calmet, who included it in A. Calmet, Bibliothèque lorraine, Nancy 1751, pp. 987-999.

${ }^{31}$ Voltaire to de Formont, 25 June 1735 [in:] Voltaire, Euvres complètes, Paris, v. 11, 1837, p. 159 ("J'ai été à la cour de Lorraine (...). Il y a là un établissement admirable pour les sciences, peu connu et encore moins cultivé. C'est une grande salle toute meublée des expériences nouvelles de physique, et particulièrement de tout ce qui confirme le système newtonien. Il y a pour environ dix mille écus de machines de toute espèce. (...) Il n'y a en France rien de pareil à cet établissement").

${ }^{32}$ Poleni to Algarotti, 13 January 1746: BCVr, Carteggio Poleni, Vol. 1, pp. 127-128.

${ }^{33}$ G.N. Vlahakis, An outline of the introduction of classical physics in Greece. The role of the Italian universities and publications, "History of Universities" 1998, Vol. XIV, pp. 157-180. 
that characterised the Enlightenment. It is however important to point out that Poleni's scientific interests, his ideas, as well as the peculiarities of the Paduan and Italian context, provided the university collection of Padua, as we have seen, with an identity of its own, so that Padua in turn enriched with peculiar and new elements the diffusion of experimental philosophy lecturing in Europe.

What happened after Poleni's death? The Cabinet of Physics was regularly enlarged with new devices mainly intended for teaching and, in some cases, for research. We will outline those of Poleni's successors who contributed to the development of the Cabinet of Physics in a significant way.

Among them, let's mention at first Salvatore Dal Negro, who was professor of experimental physics in Padua from 1806 to $1839 .{ }^{34}$ Dal Negro acquired hundreds of new instruments for the Cabinet of Physics both for teaching and for his researches. He had many instruments made by Francesco Tessarolo, who was appointed as mechanics of the Cabinet of Physics from 1806 to 1842. Many of these devices were designed by Dal Negro himself or encompassed improvements he had introduced. The scientist also bought devices from other mechanics, such as two air-pumps, which were respectively sent by the head of the workshop of Vienna Polytechnic Institute, Andreas Jaworsky, and by the mechanics of Milan Observatory, Carlo Grindel..$^{35}$ As for the instruments Dal Negro needed to study meteorology and heat, he got most of them from his friend Angelo Bellani, scientist, inventor of new devices and instrument-maker, who set up an active workshop in Monza, near Milan. It is interesting to point out that it was difficult for Dal Negro to buy instruments in France, due to a specific law of the Austrian Empire - after the fall of the Venetian Republic, the Veneto region had been ruled by the French from 1797 to 1815, then by the Austrian Empire until it was annexed by Italy in $1866 .{ }^{36}$

Just like Poleni, Dal Negro also acquired some older instruments which he needed for teaching, like for instance a couple of astrolabes and an armillary sphere. The Museum still houses one of the two astrolabes and the armillary sphere. Both are astounding instruments. The astrolabe is signed "Renerus Arsenius Nepos Gemme Frisy Faciebat Louany 1566" and it encompasses stars that are situated at the south of the Capricorn Tropic, which makes it unique. As for the armillary sphere, it is made of three concentric spheres inserted one into the other, to represent the eighth, ninth and tenth sphere of the Ptolemaic Universe (Fig. IX). It thus demonstrates not only the precession of the equinoxes and the apparent 24-hours movement of the stars around the Earth, but also the trepidation of the equinoxes. The trepidation theory was introduced in the Middle Ages and abandoned at the end of the $16^{\text {th }}$ century. Such armillary spheres are today extremely rare, but it seems they had no value at all at the time, as Dal Negro's papers show that it was less expensive for him to buy the old sphere than to have a new one made. Let's add that we have valuable details about the way Dal Negro organised his lectures and on

${ }^{34}$ F. Marcon, S. Talas, Salvatore Dal Negro [in:] Clariores. Dizionario biografico dei docenti e degli studenti dell'università di Padova, ed. P. Del Negro, Padua 2015.

${ }^{35}$ Dal Negro to the University of Padua, February 1826, ASUP, Rettorato 1825, busta 42; Dal Negro to the University of Padua, 6 August 1828, ASUP, Rettorato 1825, busta 42.

${ }^{36}$ Letter of the Imperiale Regio Governo to the Rettore Magnifico dell'I.R Università di Padova, 29 September 1826, ASUP, Rettorato 1825, busta 42. 
how he used the Cabinet's instruments thanks to one of his students, who described the physics lectures he attended in 1824-1825. ${ }^{37}$

As for his researches, Dal Negro focused on electricity. Contrarily to Poleni, who directly published his papers on the main European scientific journals of the time, Dal Negro mainly published his contributions at first in the quite local Annali delle Scienze del Regno Lombardo Veneto, then many of his papers were translated and republished in European journals. ${ }^{38}$ In particular, Dal Negro was widely acknowledged as the inventor or one of the inventors of electrical motors. He actually invented various models of electrical motors, from the first ones, proposed in the years 1831-1834, made of magnets of various shapes that oscillated like pendulums, to the models he called "electrical rams," devised in the years $1836-1838 .{ }^{39}$ His pendulum motors are the most widely known of his inventions. A paper about them was for instance published in 1834 in the Bibliothèque Universelle, while Louis Figuier, in Les merveilles de la science, 1868, wrote that «la plus ancienne tentative pour appliquer à un travail utile l'action des aimants artificiels appartient à l'abbé Salvator Dal Negro, savant ecclésiastique de Padoue», and Sylvanus Thompson, in The electromagnet and electromagnetic mechanism, London, 1891, specified that »Among those who now proposed the construction of electromagnetic motors were Henry, Dal Negro and Ritchie. Henry and Dal Negro's motors were of the oscillatory type«. Let's add that all Dal Negro's motors were given further visibility in 1876 , when photographs of them were sent to the Loan Collection of Scientific Apparatus, the big scientific exhibition that was held in London in the building of the 1862 Universal Exhibition (Fig. X). Furthermore, some of Dal Negro's instruments were sent to the Exposition Internationale d'électricité in Paris in 1881 and they were thus described in 1883 in the journal La lumière électrique as the first ever invented electrical motors. Several of Dal Negro's prototypes are still kept at the Museum of the History of Physics in Padua.

Among Dal Negro's successors, Francesco Zantedeschi, who taught in Padua from 1849 to 1857 , also enthusiastically cared for the Cabinet of Physics. ${ }^{40}$ It seems he was the first to acknowledge the historical value of the Cabinet, underlining that many of its instruments had been invented, made, used or acquired by illustrious scholars. He published a paper in in this sense in 1858, where he presented the history of the Cabinet and described what he regarded as the highlights of the collection. These included several

37 The manuscript is kept at the Marciana National Library in Venice (Luigi Nardo da Chioggia, Lezioni di Fisica date dal Prof. Ab. Dal Negro l'Anno Scolastico 1824-25, Ms It. IV, 744 (=10610)).

${ }^{38}$ Dal Negro's works on electro-magnetic induction were for instance published at first in 18311832 in the Annali delle Scienze del Regno Lombardo Veneto, then translated in in 1832 and in 1833 in the Viennese Zeitschrift fur Physik un verwandte wissenschaften, presented in 1834 in Poggendorff's Annalen der Physik und Chemie (published in Leipzig), and mentioned in 1898 in Wiedemann's Lehre von der electricitat (published in Braunscheig). They were also described by Sylvanus P. Thompson in his 1891 Lectures on the electromagnet, published in New York, and by H. du Bois in his 1896 book The magnetic circuit in theory \& practice, also published in New York.

${ }^{39}$ For a description of Dal Negro's motors, see for instance: S. Dal Negro, Nuova macchina elettro-magnetica immaginata dell'Abate Salvatore Dal Negro, "Annali delle Scienze del Regno Lombardo-Veneto," March/April 1834, Vol. 4, $2^{\text {nd }}$ bimestre; idem, Descrizione degli arieti elettro-magnetici tanto semplici, quanto composti, “Annali delle Scienze del Regno Lombardo-Veneto" 1838, Vol. 8.

${ }^{40}$ F. Marcon, S. Talas, Francesco Zantedeschi [in:] Clariores... 
of Poleni's instruments and Dal Negro's motors. ${ }^{41}$ Having travelled in Germany and France, Zantedeschi was in touch with figures like Berzelius, Arago, Babinet, Oersted and Brewster. In Paris, where he spent long periods of time, he met many of the best instrument-makers and bought lots of instruments, focusing on optical devices. Due to his contacts, he also received several instruments as gifts: Gourjon, mechanics of the Ecole Polytechnique in Paris, sent him for instance in 1852 a Brewster stereoscope and several stereoscopic daguerreotypes, made by Duboscq Soleil's workshop, which are still kept in Padua and are quite rare today (Fig. XI). ${ }^{42}$

A few years later, very good contacts with the Austrian, German and French scientific communities were also forged by Francesco Rossetti, who became professor of physics in Padua in $1866 .{ }^{43}$ Rossetti actually studied in Vienna and he visited various German towns, meeting several of the main German scholars of those years, such as Helmholtz, Bunsen and Kirchhoff. He also attended lectures in Paris, where he worked with Regnault. When he obtained the chair of physics in Padua, he acquired new and expensive instruments for the Cabinet, which he bought in different parts of Europe. In 1872, according to his inventory, about 1600 instruments made up the Cabinet of Physics, and Rossetti then enlarged it with more than 600 new devices.

After his death, the chair of physics was assigned to Augusto Righi, one of the best Italian scientists of the time - he was the first to use microwaves to replicate Hertz' experiments on electromagnetic waves. ${ }^{44}$ During the years Righi spent in Padua, from 1885 to 1889 , Righi worked on many different fields, from electricity to optics. He designed for instance in 1889 a polistereoscope, which served as a telestereoscope, pseudoscope and iconoscope. ${ }^{45}$ The Museum still houses this very original instrument, the only existing of this kind, as well as several other devices that Righi devised or used. Let's mention for instance a huge Holtz four-disk generator and 108 Leyden jars, that Righi used all together to obtain several meters long discharges along glass plates covered with zinc, or to study slowly moving discharges shaped as luminous globes. ${ }^{46}$

The Cabinet of Physics was thus regularly updated according to the latest developments of science and it is not surprising that, as soon as the discovery of X rays was announced by Röntgen, on 28 December $1895,{ }^{47}$ X-ray plates were obtained in Padua by

${ }^{41}$ F. Zantedeschi, Dell'origine e del progresso della fisica teorica sperimentale nell'archiginnasio padovano, Venice 1858.

${ }^{42}$ F. Marcon, G. Peruzzi, S. Talas, Gli strumenti del pre-cinema del Museo di Storia della Fisica dell'Università di Padova, Padua 2016.

${ }^{43}$ F. Marcon, Francesco Rossetti [in:] Clariores...

${ }^{44}$ S. Talas, Augusto Righi [in:] Clariores...

45 A. Righi, Sopra un apparecchio stereoscopico, "Atti della Reale Accademia dei Lincei. Rendiconti" 1889, Serie 4, 286, Vol. 5, pp. 862-864. The instrument is also described in F. Marcon, G. Peruzzi, S. Talas, op. cit., note 41.

${ }^{46}$ A. Righi, Descrizione ed uso di una macchina di Holtz di costruzione speciale, "Memorie della Reale Accademia di Bologna," 17 April 1879; Alcune esperienze colla scarica di una grande batteria, "Rendiconti della Reale Accademia dei Lincei," 16 December 1888. See also G. Peruzzi, S. Talas, Bagliori nel vuoto, Treviso 2004.

47 W.C. Röntgen, Ueber eine neue Art von Strahlen. Vorläufige Mittheilung, "Sitzungsberichte der Würzburger Physikalischen-Medicinischen Gesellschaft" 1895, Vol. 37. 
Giuseppe Vicentini, who held at the time the chair of experimental physics. ${ }^{48}$ The Museum thus holds plates dated 16-18 January 1896, which means that they were produced only a couple of weeks after the publication of Röngten's paper (Fig. XII).

Finally, let us mention that Bruno Rossi, one of the giants of twentieth-century particle physics, taught at the University of Padua from 1932 to 1938, radically transforming both research and teaching. ${ }^{49}$ As a pioneer of cosmic-ray physics, he introduced in Padua this new research field, while he planned and supervised the construction of the new Institute of Physics. The new building hosted laboratories specifically intended for students' training activities, as well as forty-two research laboratories. Rossi also started the construction of a Cockroft-Walton accelerator, which he could not finish because, in 1938, he was asked to leave the University due to the Italian Racial Laws. After spending some time with Niels Bohr in Copenhagen and with Patrick Blackett in Manchester, Rossi left Europe and spent the rest of his life in the United States, mainly at the MIT in Boston. The instruments he left in Padua, such as his Geiger counters, a cloud chamber and a powerful 7-tons electromagnet, were extremely useful for Padua physicists to learn and train in the difficult days after WWII. Rossi's devices are now housed at the Museum of the History of Physics, together with other twentieth-century devices, such as the first working bubble chamber constructed in Europe, made in Padua in 1955 by a group led by Pietro Bassi, ${ }^{50}$ and the first bubble chamber used at CERN, in Geneva, in 1958-1959 - this is a two-litre propane chamber, devised and made in Padua in 1956 (Fig. XIII). ${ }^{51}$

Before turning to the current acquisition policy of the Museum, let us spend a few words about some peculiarities of the nineteenth- and twentieth-century part of the collection. First of all, it is worth underlining the importance of the official "mechanics" of the Cabinet of Physics, who not only made new instruments under the guidance of the physics professors but often contributed to repair the existing devices as well. These mechanics also worked for other cabinets of the University, like the Cabinet of Topography, as well as for external "clients," such as the high schools' of the region that held cabinets of physics. They thus strongly contributed to the circulation of scientific knowledge between the various institutions of the Veneto region. It is also interesting to point out that many instruments of the collection were made by the inventors themselves, like the magneto-electric generator described in 1844 by Emil Störher and signed "E. Störher in Leipzig," and the dynamo-electric machine invented in 1867 by William Ladd and

${ }^{48}$ G. Vicentini, G. Pacher, Esperienze coi Raggi di Roentgen, "Memorie del Reale Istituto Veneto di Scienze, Lettere ed Arti" 1896, Vol. 25, No. 7, pp. 3-18. For a short biography of Vicentini, see F. Marcon, Giuseppe Vicentini [in:] Clariores...

${ }^{49}$ See for instance: G. Peruzzi, S. Talas, The Italian contributions to cosmic-ray physics from Bruno Rossi to the G-Stack. A new window into the inexhaustible wealth of nature, La rivista del Nuovo Cimento della Società Italiana di Fisica 2007, Vol. 30, pp. 197-257; G. Busetto, G. Peruzzi, E. Prandini, S. Talas, L. Tibaldo, Bruno Benedetto Rossi [in:] B. Rossi, L'enigma dei raggi cosmici, Padua 2012, pp. 3-18.

${ }^{50}$ P. Bassi, P. Mittner, I. Scotoni, A half liter "clean” bubble chamber, "Il Nuovo Cimento" 1955, vol. 2, p. 1334; P. Bassi, A. Loria, J.A. Meyer, P. Mittner, I. Scotoni, On n-Pentane Bubble Chambers, "Il Nuovo Cimento" 1956, Vol. 4, pp. 491-500.

${ }^{51}$ A. Loria, P. Mittner, I. Scotoni, G. Zago, Camera a bolle a propano, "Il Nuovo Cimento" 1959, Vol. 11, pp. 718-724; A. Loria, P. Mittner, R. Santangelo, I. Scotoni, G. Zago, The Scattering of Positive 120 Mev Pions on Protons, "Il Nuovo Cimento" 1961, Vol. 22, pp. 820-843. 
signed "W. Ladd / London." 52 In some cases, the inventors themselves directly sent their instruments to their colleagues in Padua. Salvatore Dal Negro received for instance from Leopoldo Nobili, in 1830, one of his astatic galvanometers - an instrument that was to become one of the most popular and diffused devices of the time - while he got in 1824 from Giovanni Battista Amici one of his reflection microscopes (Fig. XIV).

Today, the Museum goes on collecting contemporary physics instruments but, as we cannot keep all the stuff produced, we select only objects devised or made in Padua, as well as instruments that were used by Padua physicists and played a noteworthy role in research or teaching. However, physicists and technicians are usually used to recycle or get rid of what they do not need any longer. They do not feel they are "generating" stuff that could become heritage in the future. To make scientists and technicians conscious of the long-term cultural importance of the material they design, produce and handle in their everyday work, we thus started organising small, low-cost exhibitions in front of the Department of Physics' library, a space that physicists, technicians and students usually frequent on their everyday activities. Focusing around very recent instruments, these exhibitions aim at stimulating the Department's staff to become first-line actors for the preservation of recent scientific heritage. They also intend to reveal pages from the twentieth- and twenty-first century life of the Physics Department and to examine the role of objects in the construction of scientific knowledge.

For instance, at the beginning of 2013, we were offered a Time Projection Chamber (TPC), a special type of particle detector, designed by Paduan physicists and used for an international collaboration experiment that was carried out in France. We gathered all the possible documents and objects related to it and to the experiment it was used for, the so called MUNU experiment (MU stands for the Greek letter $\mu$, which is traditionally used to represent the magnetic moment; NU stands for the Greek letter $v$, which is used to represent neutrinos), which aimed at measuring the magnetic moment of neutrinos. Of course, we collected prototypes and other related instruments, photos, published papers and laboratory notes. We also conducted an interview with Carlo Broggini, the physicist who proposed the chamber to the Museum, one of the leading figures of the MUNU experiment. Some restoration work was carried out by Daniele Filippi, the technician who had worked on and with the TPC chamber within the MUNU experiment. As for the exhibition, we went to the core of science practice through an analysis of the process from the inside, carrying out somewhat like a dissection of the TPC and of the related experiment (Fig. XV). ${ }^{53}$

The outcome of exhibitions of this kind is quite clear: more and more often, physicists call the Museum when they have to dismantle an experiment or parts of it, and much material is thus preserved. We are right now working on AURIGA, a gravitational antenna that has been recently dismissed. ${ }^{54}$ AURIGA itself will remain as a kind of icon in the garden of Legnaro National Laboratories, near Padua, where it was in use from 1989 to

52 G. Peruzzi, S. Talas, Bagliori nel vuoto..., note 45.

${ }^{53} \mathrm{~S}$. Talas, At the core of scientific research, pages from the life of a Department of Physics [in:] P. Ruiz, Beyond public engagement, new ways of studying, managing and using University collections, ed. P. Ruiz Castell, Newcastle upon Tyne 2015, pp. 97-103.

${ }^{54}$ See http://www.auriga.lnl.infn.it/ [access: 12.05.2019]. 
2017. At the Museum of the History of Physics, we will keep not only the drawings, photos, laboratory notes, itd., that will constitute AURIGA's archive, but also all the devices or parts of devices that were used for tests or in the previous versions of the antenna, in order to keep the history of AURIGA and its developments really alive.

The preservation of recent scientific stuff is actually the only way to keep our Museum's nature, as the collection will thus represent the material evidence of the physics teaching and research activities that were carried out in Padua not only in the past centuries but today as well. As we have seen, the contacts that were set up throughout the centuries between Paduan physicists and the international scientific community are clearly documented by the collection. Today, physics is more and more based on transnational collaborations and the Museum of the History of Physics, as well as all university museums of this kind, has thus to be prepared to illustrate to future generations not only the current international dimension of Padua physics, but also the international dimension of scientific research in itself.

\section{Bibliography}

AA.VV., Giovanni Poleni nel bicentenario della morte, Padua 1963.

AA.VV., Giovanni Poleni, idraulico, matematico, architetto, filologo, Padua 1988.

AA.VV., La curiosità e l'ingegno, Padua 2000.

The art of teaching physics: The eighteenth-century demonstration apparatus of Jean Antoine

Nollet, eds. L. Pyenson, J.F. Gauvin, Sillery 2002.

Bassi P., Loria A., Meyer J.A., Mittner P., Scotoni I., On n-Pentane Bubble Chambers, "Il Nuovo Cimento" 1956, Vol. 4, pp. 491-500.

Bassi P., Mittner P., Scotoni I., A half liter “clean” bubble chamber, "Il Nuovo Cimento" 1955, Vol. 2, p. 1334.

Beyond public engagement, new ways of studying, managing and using University collections, ed.

P. Ruiz Castell, Newcastle upon Tyne 2015.

Bois H. du, The magnetic circuit in theory \& practice, New York 1896.

Busetto G., Peruzzi G., Prandini E., Talas S., Tibaldo L., Bruno Benedetto Rossi [in:] B. Rossi, L'enigma dei raggi cosmici, Padua 2012, pp. 3-18.

Cabinets of experimental philosophy in eighteenth-century Europe, eds. J. Bennett, S. Talas, Leiden-Boston 2013.

Calmet A., Bibliothèque lorraine, Nancy 1751.

Clariores. Dizionario biografico dei docenti e degli studenti dell'università di Padova, ed. P. Del Negro, Padua 2015.

Clercq P. de, At the sign of the oriental lamp. The Musschenbroek workshop in Leiden, 1660 1750, Rotterdam 1997.

Clercq P. de, The Leiden Cabinet of Physics, Leiden 1997.

Dal Negro S., Descrizione degli arieti elettro-magnetici tanto semplici, quanto composti, "Annali delle Scienze del Regno Lombardo-Veneto" 1838, Vol. 8, pp. 3-16.

Dal Negro S., Nuova macchina elettro-magnetica immaginata dell'Abate Salvatore Dal Negro, “Annali delle Scienze del Regno Lombardo-Veneto" March/April 1834, Vol. 4, pp. 67-80.

Del Negro P., L'Università [in:] Storia della cultura veneta, eds. G. Arnaldi, M. Pastore Stocchi, 10 Vol., Vicenza 1976-1986, Vol. 5/I: Il Settecento, pp. 47-76.

Desaguliers J.T., A course of experimental philosophy, 2 Vol., London 1734-1744. 
Giovanni Poleni tra Venezia e Padova, ed. P. Del Negro, Venezia 2013.

Gravesande W. 's, Physices elementa mathematica, experimentis confirmata, sive introductio ad philosophiam Newtonianam, Leiden 1720-1721, $2^{\text {nd }}$ ed. $1725 ; 3^{\text {rd }}$ ed. 1742.

Heilbron J.L., Nollet, Jean Antoine [in:] Dictionary of scientific biography, 16 Vol., New York 1970-1980, Vol. 10.

Lalande J.-J. de, Voyage d'un François en Italie, Fait dans les années 1765 et 1766, 8 Vol., Paris 1769.

Laura Bassi - Emblema e primato nella scienza del Settecento - Emblem and primacy in Settecento science, eds. L. Cifarelli, R. Simili, Bologna 2012.

Loria A., Mittner P., Santangelo R., Scotoni I., Zago G., The Scattering of Positive 120 Mev Pions on Protons, "Il Nuovo Cimento" 1961, Vol. 22, pp. 820-843.

Loria A., Mittner P., Scotoni I., Zago G., Camera a bolle a propano, "Il Nuovo Cimento" 1959, Vol. 11, pp. 718-724.

Marcon F., Francesco Rossetti [in:] Clariores. Dizionario biografico dei docenti e degli studenti dell'università di Padova, ed. P. Del Negro, Padua 2015.

Marcon F., Giuseppe Vicentini [in:] Clariores. Dizionario biografico dei docenti e degli studenti dell'università di Padova, ed. P. Del Negro, Padua 2015.

Marcon F., Peruzzi G., Talas S., Gli strumenti del pre-cinema del Museo di Storia della Fisica dell'Università di Padova, Padua 2016.

Marcon F., Talas S., Francesco Zantedeschi [in:] Clariores. Dizionario biografico dei docenti e degli studenti dell'università di Padova, ed. P. Del Negro, Padua 2015.

Marcon F., Talas S., Salvatore Dal Negro [in:] Clariores. Dizionario biografico dei docenti e degli studenti dell'università di Padova, ed. P. Del Negro, Padua 2015.

Morton A.Q., Wess J.A., Public and private science - The King George III Collection, OxfordLondon 1993.

Musschenbroek P. van, Elementa physicae, Leiden 1734.

Musschenbroek P. van, Introductio ad philosophiam naturalem, Leiden 1762.

Nollet J.A., Programme ou idée générale d'un cours de physique expérimentale, Paris 1738.

Note e ricevute delle spese fatte per l'artificiosissima machina, con cui si fanno e si mostrano gli esperimenti delle forze centrali, Padua, Archivio per la Storia dell'Università di Padova (ASUP), busta 591.

Papin D., Continuation du Digesteur ou manière d'amolir les os, Amsterdam 1788.

Peruzzi G., Talas S., Bagliori nel vuoto, Treviso 2004.

Peruzzi G., Talas S., The Italian contributions to cosmic-ray physics from Bruno Rossi to the G-Stack. A new window into the inexhaustible wealth of nature, "La rivista del Nuovo Cimento della Società Italiana di Fisica" 2007, Vol. 30, pp. 197-257.

Poleni G., Indice delle macchine, BMVe, ms. it., III, 54.

Poleni G., Memorie istoriche della gran cupola del Tempio Vaticano, Padua 1748.

Poleni G., Physices elementa mathematica, experimentis confirmata, BMVe, ms. it., III, 55.

Righi A., Alcune esperienze colla scarica di una grande batteria, "Rendiconti della Reale Accademia dei Lincei” 1888, Vol. 4, ser. 4, pp. 444-447.

Righi A., Descrizione ed uso di una macchina di Holtz di costruzione speciale, "Memorie della Reale Accademia di Bologna" 1879, Vol. 10, ser. 3, pp. 94-95.

Righi A., Sopra un apparecchio stereoscopico, "Atti della Reale Accademia dei Lincei. Rendiconti” 1889, ser. 4, 286, Vol. 5, pp. 862-864.

Röntgen W.C., Ueber eine neue Art von Strahlen. Vorläufige Mittheilung, "Sitzungsberichte der Würzburger Physikalischen-Medicinischen Gesellschaft" 1895, Vol. 37, pp. 132-141.

Rossi B., L'enigma dei raggi cosmici, Padua 2012.

Salandin G.A., Pancino M., Il Teatro di Filosofia Sperimentale di Giovanni Poleni, Trieste 1987. 
Salandin G.A., Talas S., Giovanni Poleni [in:] AA.VV., La curiosità e l'ingegno, Padua 2000, pp. 85-91.

Salandin G.A., Talas S., Strumenti e macchine [in:] AA.VV., La curiosità e l'ingegno, Padua 2000, pp. 223-243.

Storia della cultura veneta, eds. G. Arnaldi, M. Pastore Stocchi, 10 Vol., Vicenza 1976-1986.

Talas S., At the core of scientific research, pages from the life of a department of physics [in:] Beyond public engagement, new ways of studying, managing and using University collections, ed. P. Ruiz Castell, Newcastle upon Tyne 2015, pp. 97-103.

Talas S., Augusto Righi [in:] Clariores. Dizionario biografico dei docenti e degli studenti dell'università di Padova, ed. P. Del Negro, Padua 2015.

Talas S., Il gabinetto di filosofia sperimentale di Poleni [in:] Giovanni Poleni tra Venezia e Pado$v a$, ed. P. Del Negro, Venezia 2013, pp. 247-275.

Talas S., La fisica nel Settecento: nuove lezioni, spettacolo, meraviglia, "Il Nuovo Saggiatore" 2011, Vol. 27, No. 5-6, pp. 37-47.

Talas S., New light on the cabinet of physics of Padua [in:] Cabinets of experimental philosophy in eighteenth-century Europe, eds. J. Bennett, S. Talas, Leiden-Boston 2013, pp. 49-67.

Talas S., Physics in the eighteenth century: new lectures, entertainment and wonder [in:] Laura Bassi-Emblema e primato nella scienza del Settecento - Emblem and primacy in Settecento science, eds. L. Cifarelli, R. Simili, Bologna 2012, pp. 177-188.

Thompson S.P., Lectures on the electromagnet, New York 1891.

Vicentini G., Pacher G., Esperienze coi Raggi di Roentgen, "Memorie del Reale Istituto Veneto di Scienze, Lettere ed Arti" 1896, Vol. 25, No. 7, pp. 3-18.

Vlahakis G.N., An outline of the introduction of classical physics in Greece. The role of the Italian universities and publications, "History of Universities" 1998, Vol. XIV, pp. 157-180.

Voltaire, Euvres complètes, Paris 1837, Vol. 11.

Zantedeschi F., Dell'origine e del progresso della fisica teorica sperimentale nell'archiginnasio padovano, Venice 1858. 
Fanny Marcon et al.

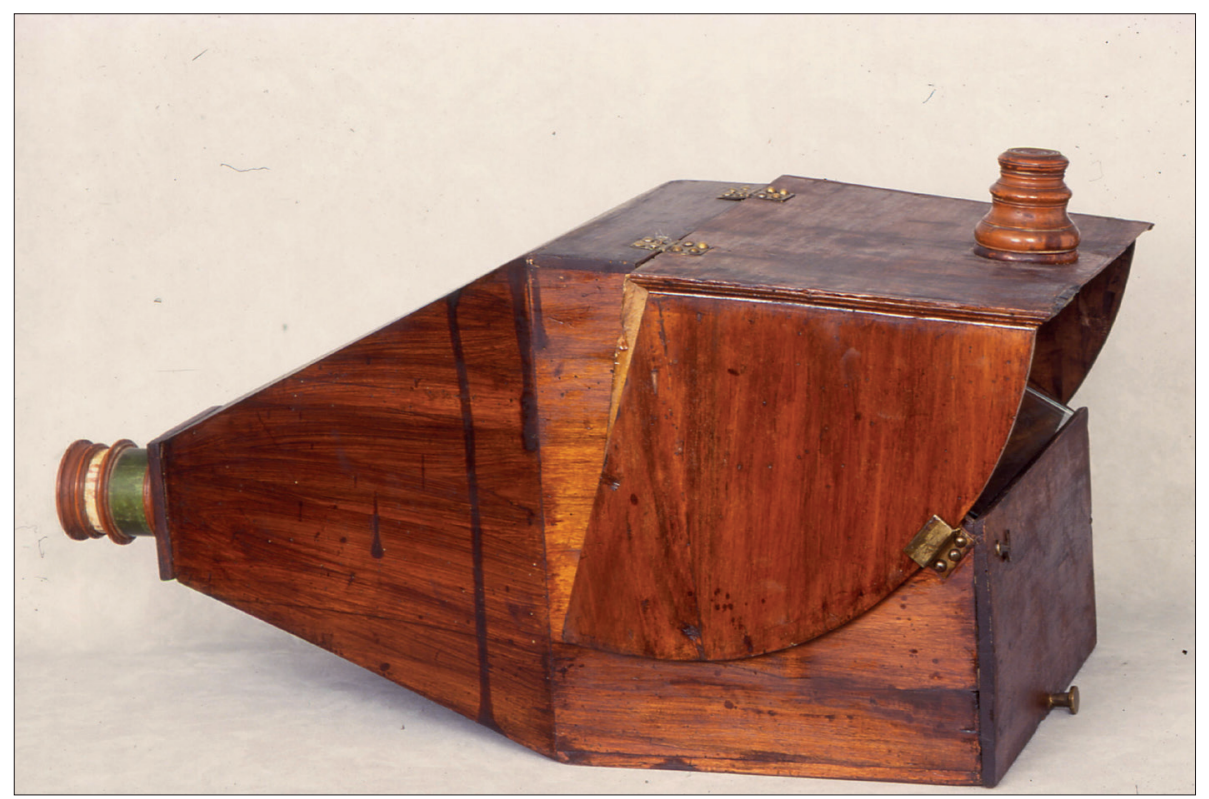

Fig. I. Camera obscura, early eighteenth century, Cabinet of Physics of Giovanni Poleni. Museum of the History of Physics, University of Padua. Photo F. Zannini

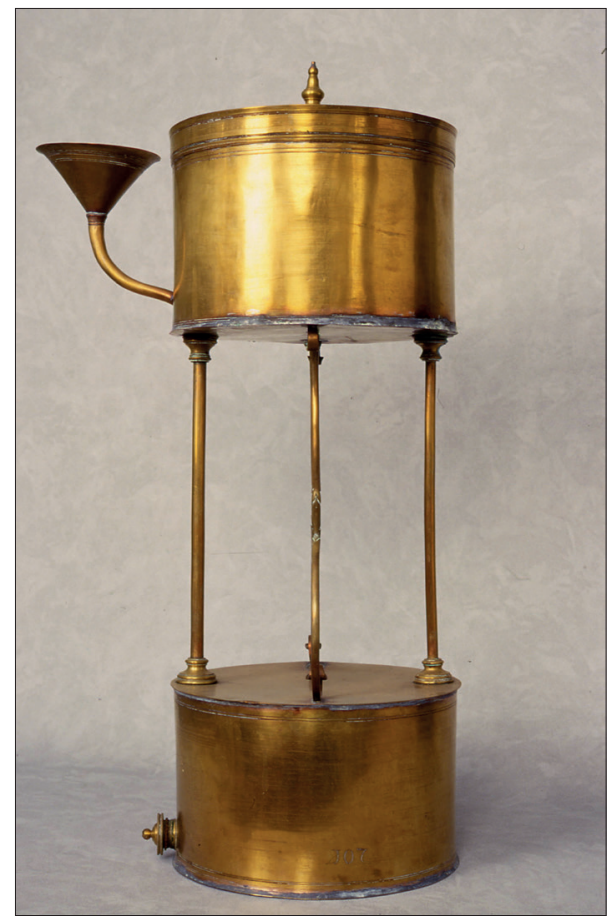

Fig. II. Hero's fountain, mid-eighteenth century, Cabinet of Physics of Giovanni Poleni. Museum of the History of Physics, University of Padua. Photo F. Zannini 


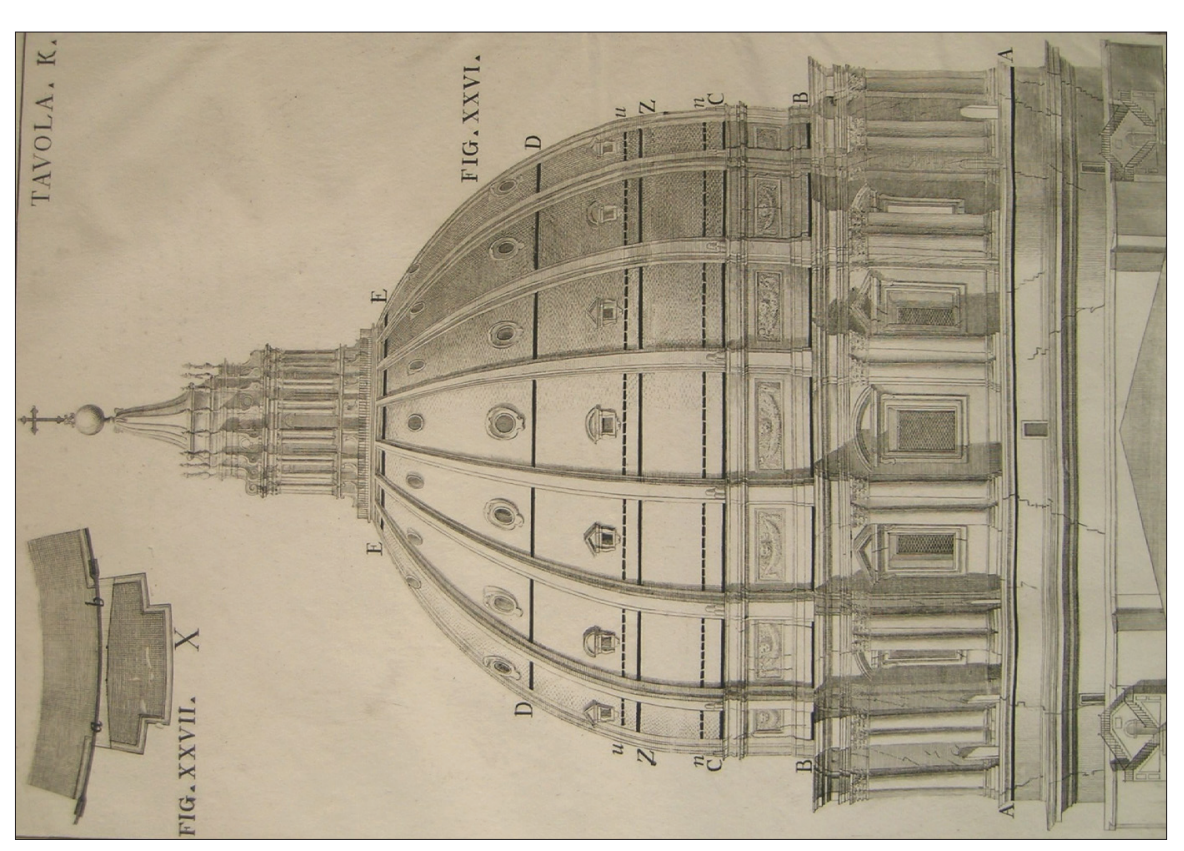

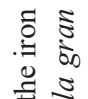

궁

.

$\frac{\pi}{2} \stackrel{\frac{2}{2}}{\pi}$

สี. ป็

ปิ

$\exists \cong$

항

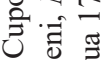

牙

0

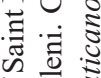

प० 1

일용

ट

50 대

ज्ञ $\frac{000}{2}$

$\geq 0$

म0

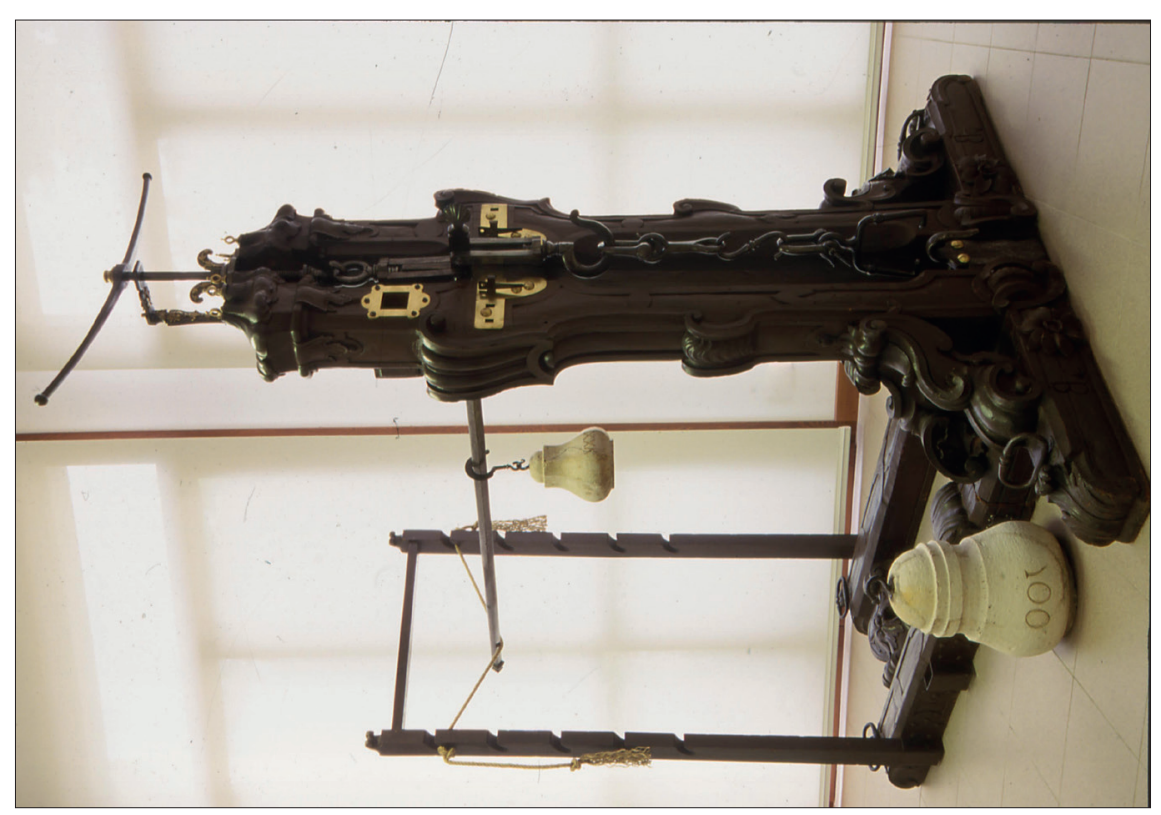

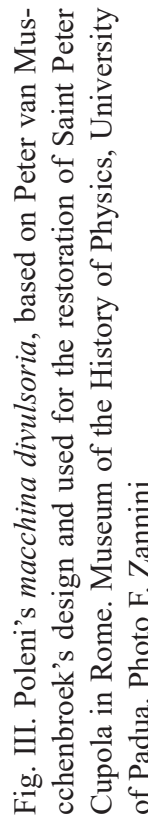




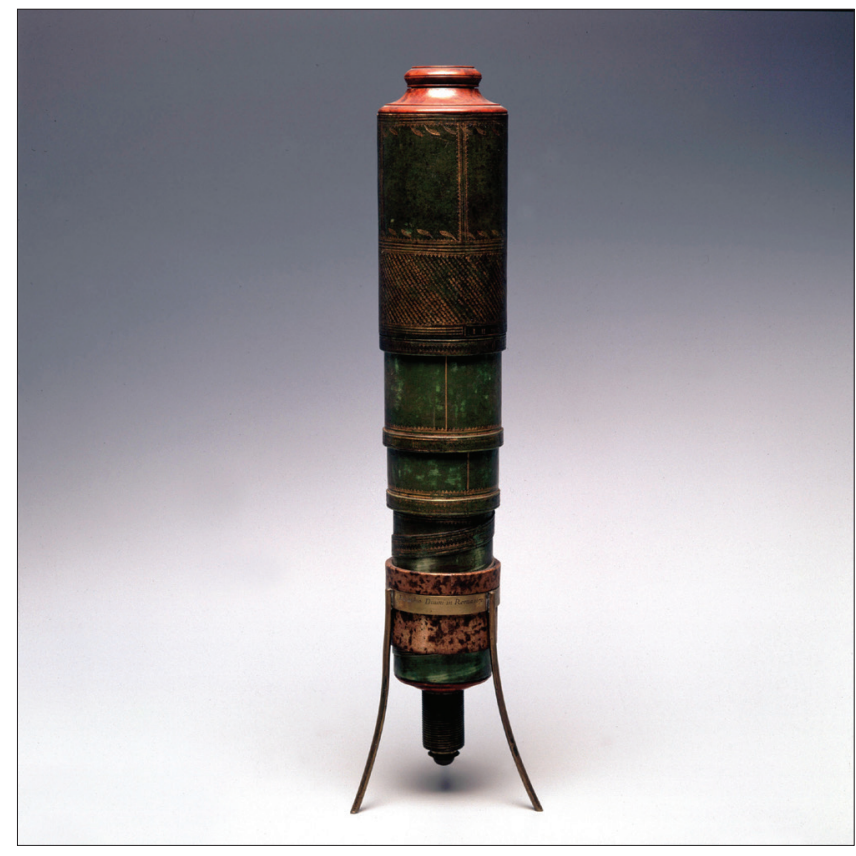

Fig. V. Microscope signed "Eustacchio Divini Roma 1671", Cabinet of Physics of Giovanni Poleni. Museum of the History of Physics, University of Padua. Photo F. Zannini

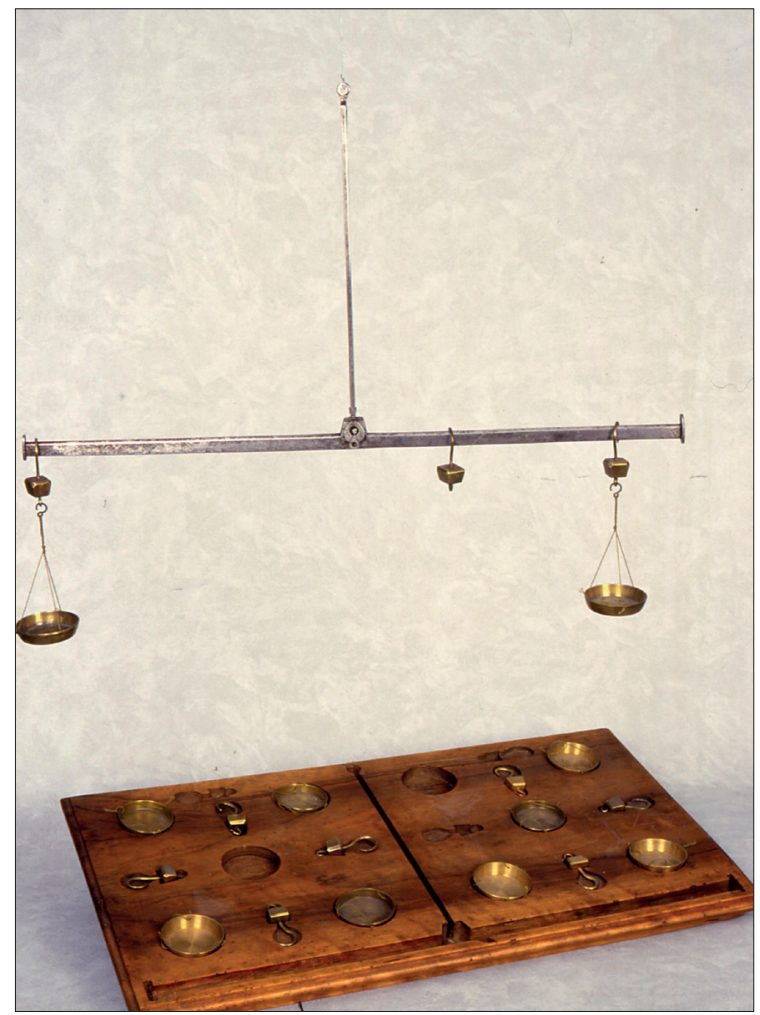

Fig. VI. Balance intended to analyse the action exerted by forces according to their distance from the fulcrum, Cabinet of Physics of Giovanni Poleni. Museum of the History of Physics, University of Padua. Photo F. Zannini 


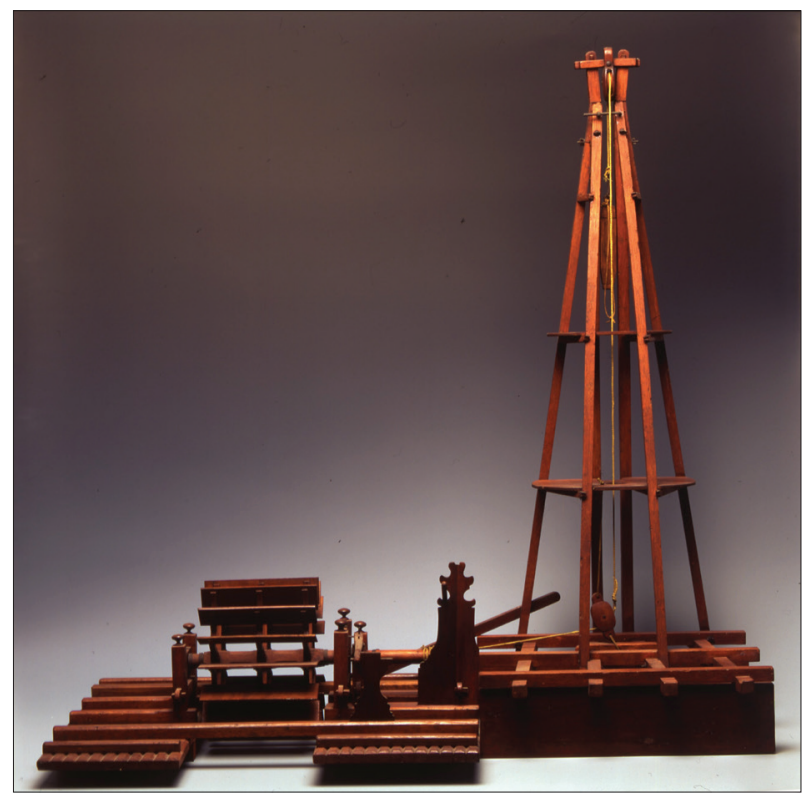

Fig. VII. Model of the pile-driver designed and made by Bartolomeo Ferracina for the reconstruction of the bridge designed by Palladio in Bassano, Cabinet of Physics of Giovanni Poleni. Museum of the History of Physics, University of Padua. Photo F. Zannini

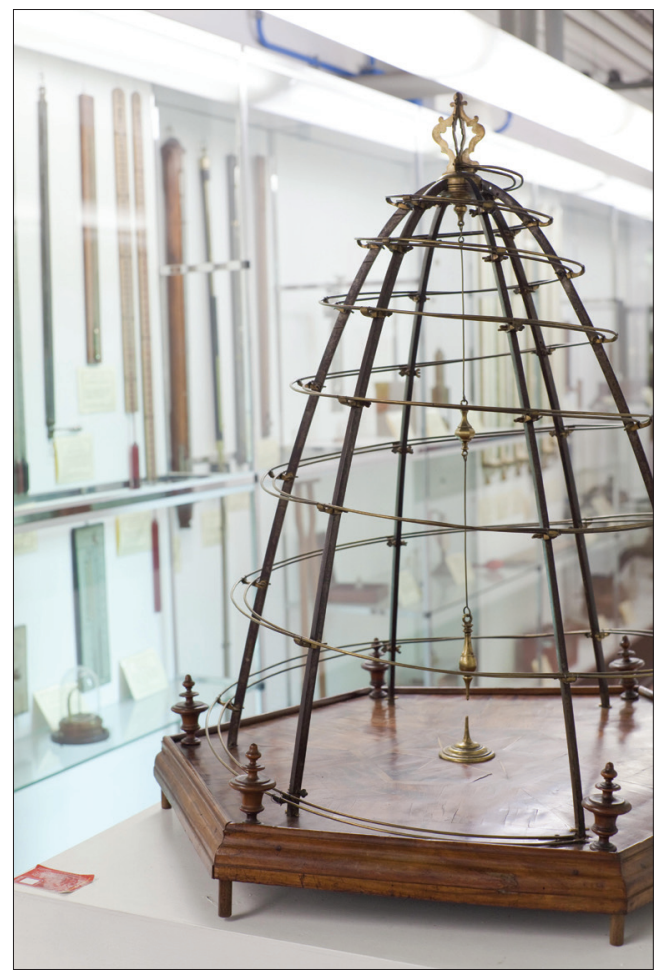

Fig. VIII. Instrument designed to demonstrate Galileo's law of falling bodies, made by Philippe Vayringe, Cabinet of Physics of Giovanni Poleni. Museum of the History of Physics, University of Padua. Photo M. Pistore 


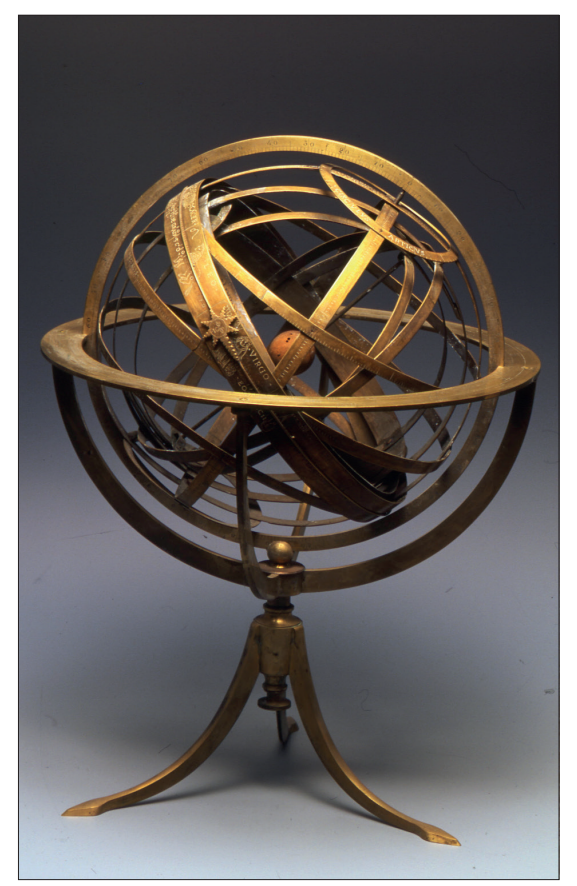

Fig. IX. Armillary sphere, acquired by Salvatore Dal Negro in the $1820 \mathrm{~s}$. The armillary sphere dates back to the sixteenth century, while the horizon and stand were made when the instrument was bought in the nineteenth century. Museum of the History of Physics, University of Padua. Photo F. Zannini

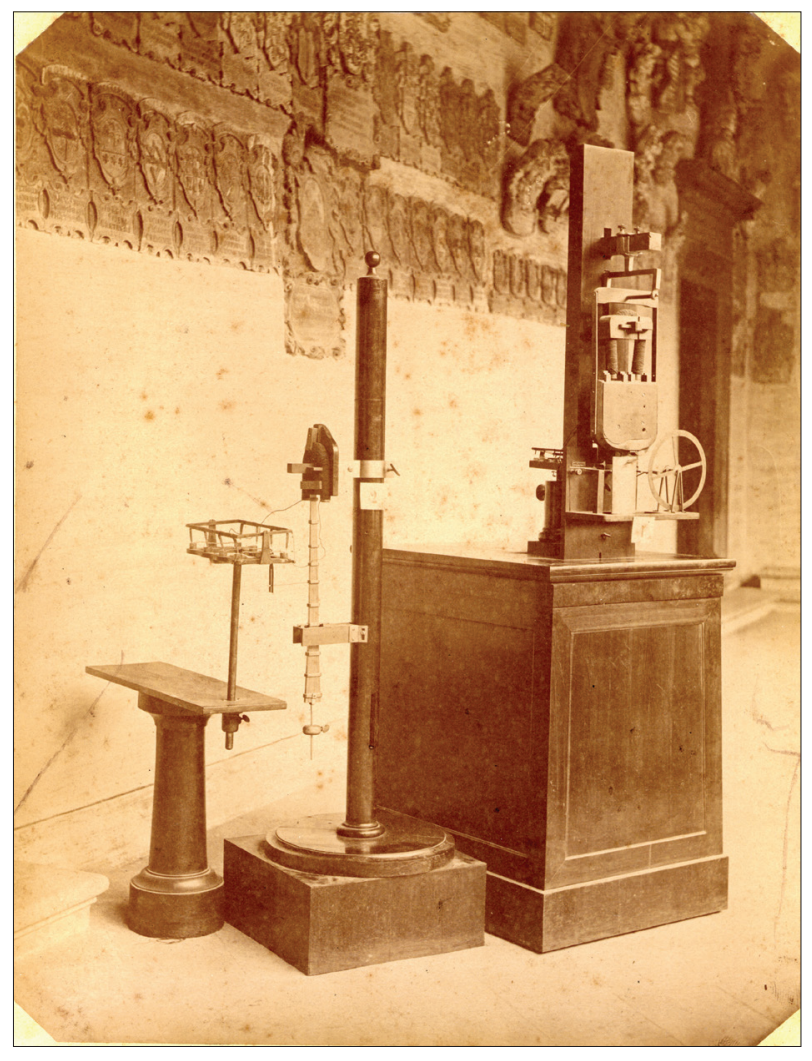

Fig. X. Two of Dal Negro's pendulum electrical motors. This photo was sent in 1876 to the Loan Collection of Scientific Apparatus, in London. Museum of the History of Physics, University of Padua. Photo author unknown 


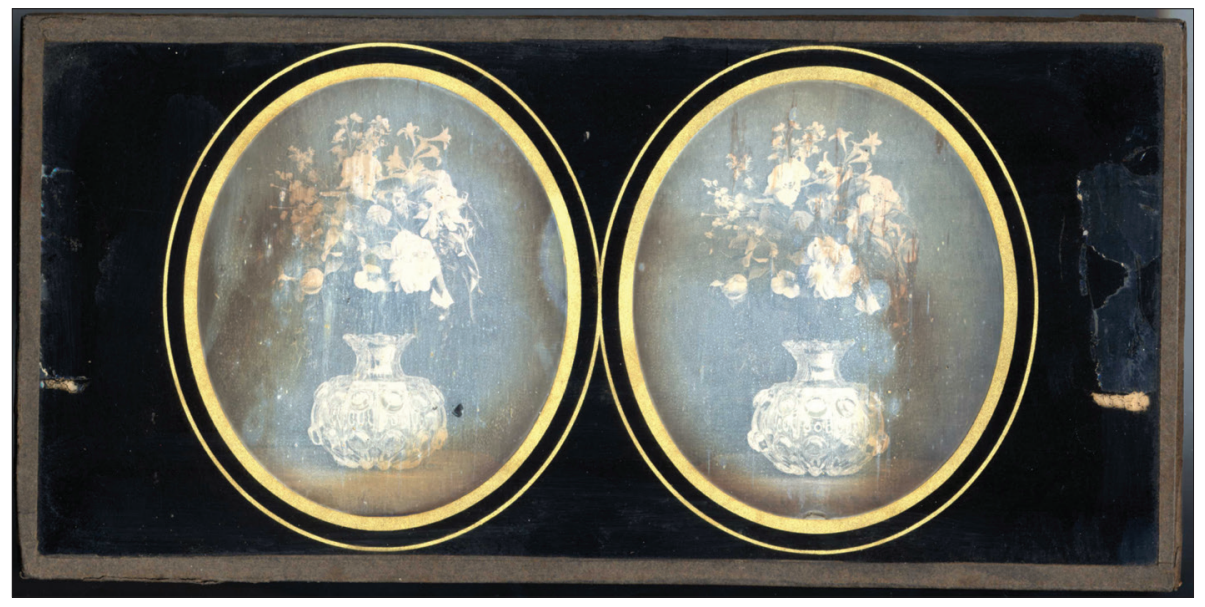

Fig. XI. One of the stereoscopic daguerreotypes made by Duboscq Soleil's workshop and sent to Francesco Zantedeschi in 1852. Museum of the History of Physics, University of Padua. Photo F. Zannini

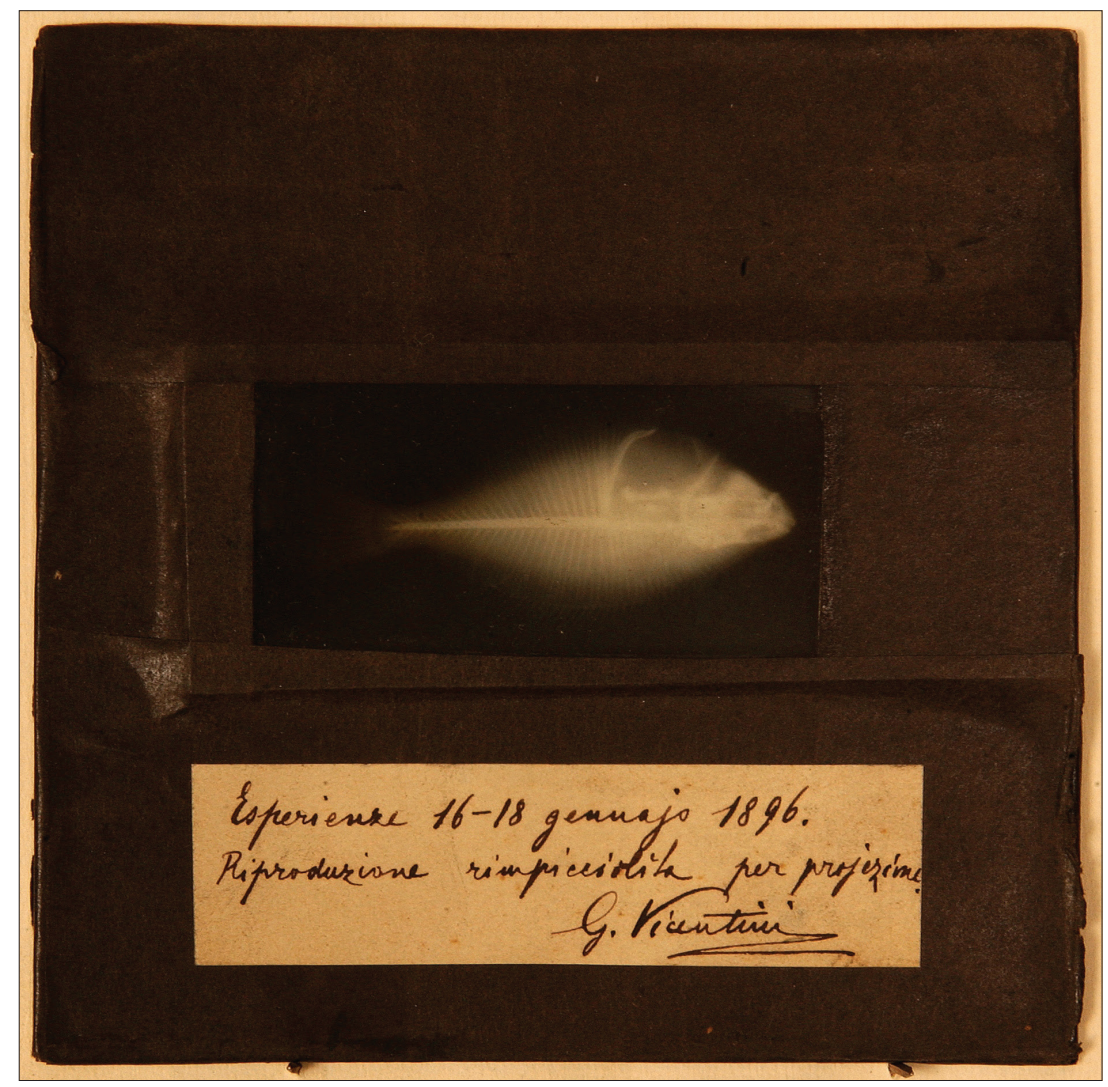

Fig. XII. Slide from an X-ray plate obtained by Giuseppe Vicentini in 1896. Museum of the History of Physics, University of Padua. Photo F. Zannini 

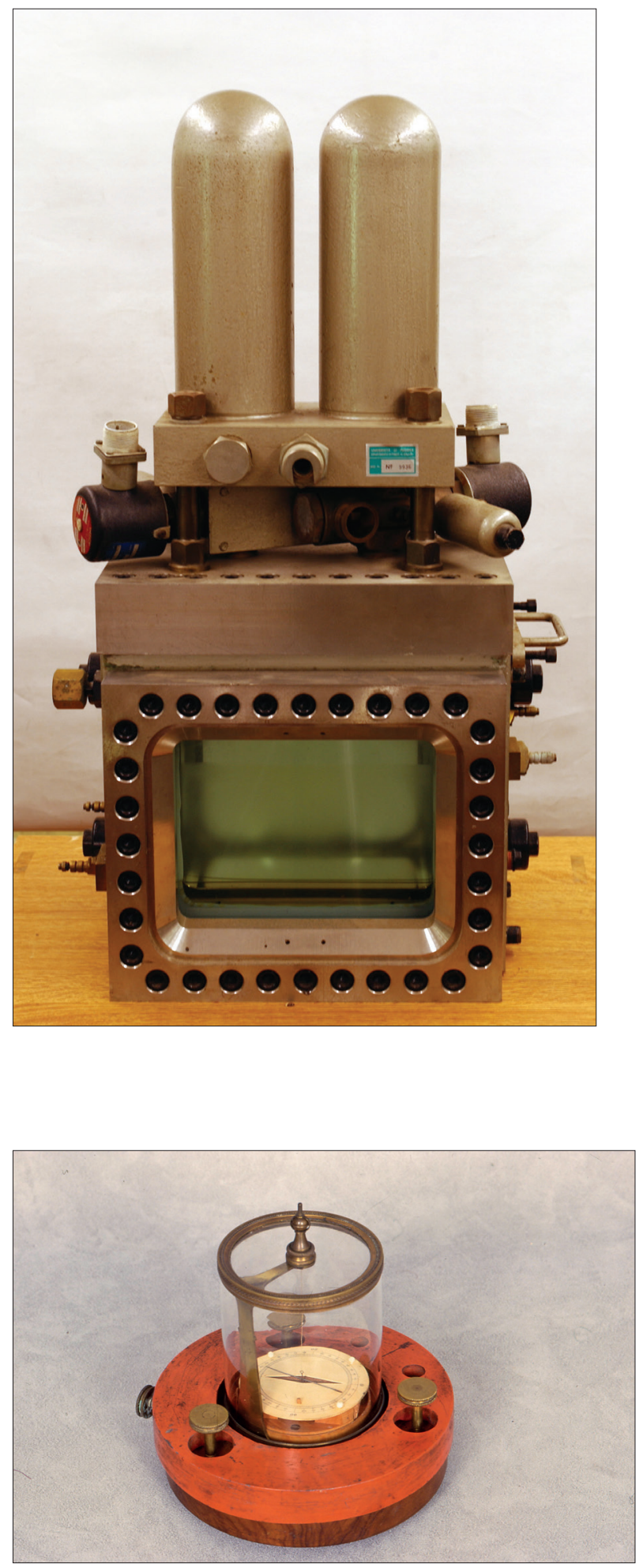

Fig. XIII. The two-litres propane bubble chamber devised in Padua in 1956 and used at CERN in 1958-1959, Geneva. Museum of the History of Physics, University of Padua. Photo F. Zannini

Fig. XIV. Astatic galvanometer devised by Leopoldo Nobili, who personally sent it to Salvatore Dal Negro in 1830. Museum of the History of Physics, University of Padua. Photo F. Zannini 


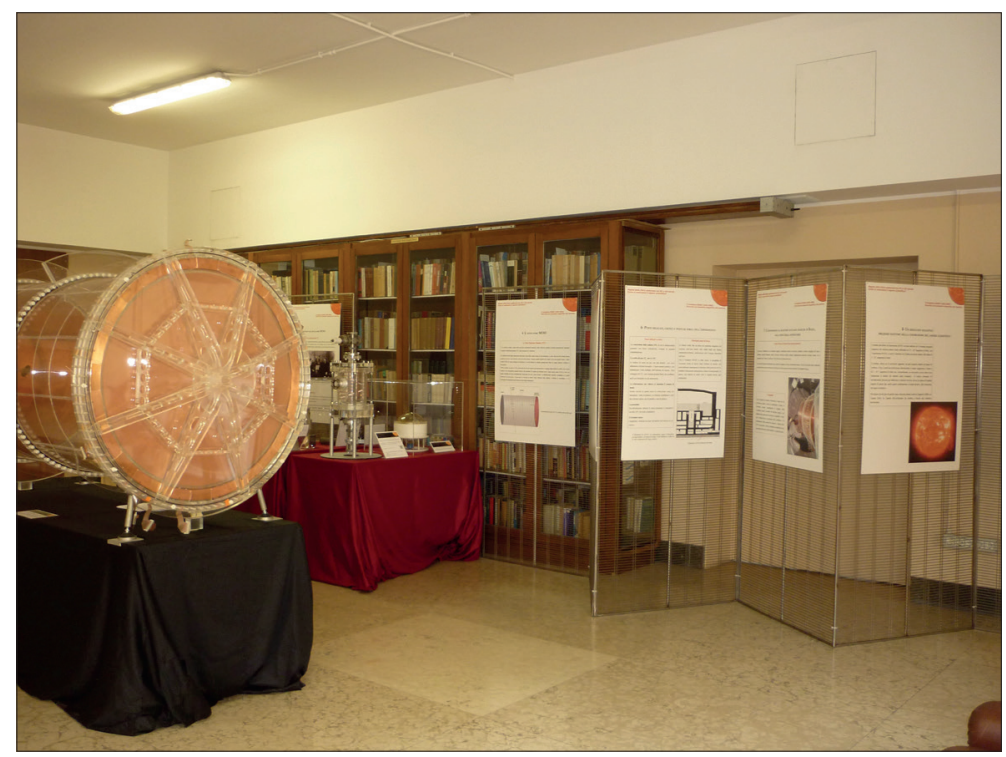

Fig. XV. Part of the MUNU exhibition, held at Padua Department of Physics in 2013. On the left, the Time Projection Chamber. Museum of the History of Physics, University of Padua. Photo F. Marcon 